\title{
Vera Hirschmann
}

\section{Die Kirche der Reinen}

Kirchen- und sozialhistorische Studie zu den Novatianern im 3. bis 5. Jahrhundert

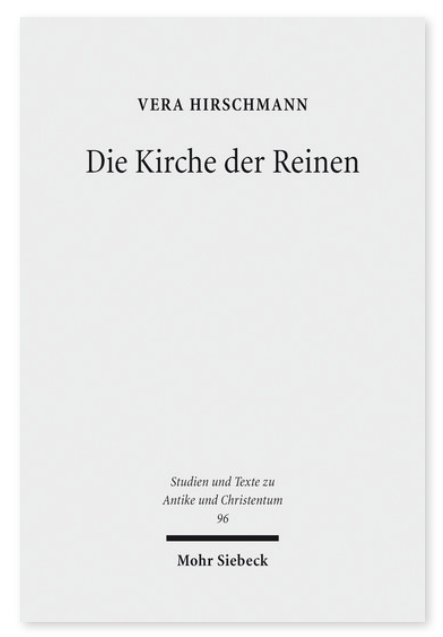

2015. XV, 229 Seiten. STAC 96

ISBN 978-3-16-153959-6

DOI 10.1628/978-3-16-153959-6

eBook PDF 89,00€

ISBN 978-3-16-153958-9

fadengeheftete Broschur 89,00€
Als in Rom im Jahre 251 die sogenannte decische Christenverfolgung ein Ende fand, begann ein innerkirchliches Drama der zuerst in der römischen Gemeinde, später aber unter allen Christen in der damaligen Welt Aufruhr schürte. Beseelt von dem Gedanken einer »reinen« Kirche, in der die Sünder keinen Platz mehr haben sollten, gründete Novatian eine Sonderkirche, die schnell im Römischen Reich Anhänger fand. Wer waren diese Gläubigen, die die christliche Entwicklung großer Teile des westlichen Kleinasiens beeinflusst zu haben schienen? Ihre Lehren waren unbequem, streng und rigoristisch, ihre Auffassung von Gott in den Augen anderer Christen oft unbarmherzig. Dennoch besaßen sie eine Attraktivität, die ihnen (wie lange??) ein Überleben trotz Anfeindungen und Verfolgungen ermöglicht hatte. Vera Hirschmann spürt dieser Attraktivität nach und setzt sich mit der Kirche der Novatianer bewusst nicht von vornherein als einer »Häresie«, sondern als einer echten Alternative für viele damalige Christen auseinander.

Vera Hirschmann Geboren 1967; Studium der Alten Geschichte, Mittelalterlichen Geschichte und Latein; 1996 Magister; 2001 Promotion; seit 2003 Wiss. Mitarbeiterin am Wissenschaftlich-Theologischen-Seminar der Universität Heidelberg im Projekt »Pepouza and Tymion Archaeological Surface Survey".
Jetzt bestellen:

https://mohrsiebeck.com/buch/die-kirche-der-reinen-9783161539596?no_cache=1

order@mohrsiebeck.com

Telefon: $+49(0) 7071-923-17$

Telefax: $+49(0) 7071-51104$ 